\title{
TREATMENT WETLANDS FOR LANDFILL LEACHATES - CASE STUDIES FROM NORWAY
}

\author{
Ketil Haarstad, Trond Maehlum and Per I. Kraft \\ Jordforsk, Norwegian Centre for Soil and Environmental Research, F. A. Dahls \\ v. 20, 1432 As, Norway
}

\section{SUMMARY}

The paper describes operational experiences of landfill leachate treatment systems at three Norwegian landfill sites, with emphasis on the reduction of $\mathrm{COD}$, nitrogen and $\mathrm{Fe}$ concentrations. The leachate systems described consist of aerated lagoons with aspirator propeller aerators/mixers, and horizontal subsurface flow treatment wetlands. Results of leachate monitoring and treatment efficiencies are presented. Operational data show that leachate treatment with aerated lagoons has problems with removal of organic matter and nitrogen, but remove Fe. Failure seems to depend on high loads (especially in winter times), sludge erosion and toxicity. The hydraulic retention time should to be $>20$ days to keep the nitrifiers in the lagoon during periods with low temperatures. Simple filtration techniques with e.g. bark, shell or coral sand, crushed concrete and others can improve leachate quality both during and after other treatment stages and remove nitrogen, colour, heavy metals, organic pollutants and pesticides, and buffer $\mathrm{pH}$ and add other nutrients. A combination of aeration, dams and filtering techniques probably gives the best treatment options.

\section{INTRODUCTION}

Activated sludge systems are extensively used for leachate treatment in Europe. The leachate treatment method that used to be most common in the UK, extended aeration activated sludge, has relatively long retention time (3-10 days) with good results for removal of $\mathrm{C}$ and $\mathrm{N}$. This is a common treatment method also in the rest of Europe (Ashbee and Fletcher 1993). Traditional activated sludge systems are generally not optimal due to high variation in leachate quality. Typical problems are foaming, precipitation and excessive sludge production. Aerated lagoon systems are the most frequent treatment option also in Scandinavia. It is a simple concept without recirculation of sludge and a high removal of $\mathrm{C}$ (Maris et al., 1994). Additional P is often recommended to enhance the biological processes (Robinson, 1997; Britz 1995; Mæhlum et al., 1998). Minimal maintenance with retention time usually in the order of 3-20 days.

On-site treatment of landfill leachate is not widespread in Norway. Fewer than 20 of the 350 municipal sanitary waste (MSW) landfills use on-site biological treatment systems. About 35 landfills discharge raw leachate to sewers without on-site pretreatment. New regulations require that most landfills must be built with a liner to control leachate; and leachate treatment is compulsory. On-site "high-tech" leachate treatment systems are avoided due to high construction and operation costs. Low-cost treatment methods operating in cold climate need to be implemented. Several studies conclude that aerating lagoons removes $\mathrm{COD}$ and $\mathrm{NH}_{4}-\mathrm{N}$ 
(e.g. Maris and Harrington, 1984, Robinson and Maris, 1985, Robinson and Grantham, 1988, Robinson, 1990). Constructed wetlands (CWs) have been used successfully as secondary and tertiary treatment of effluent from aerated lagoons in UK (Robinson, 1993) and USA (Martin and Moshiri, 1995). CW properties that make them suitable for wastewater treatment include extensive adsorptive surfaces (sediments, plants and roots), aerobic-anaerobic interfaces, and diverse, active microbial populations, which will translocate, metabolise, or use the various contaminants. According to Robinson et al. (1997) there are no technical barriers to the treatment of landfill leachates to whatever standards are appropriate.

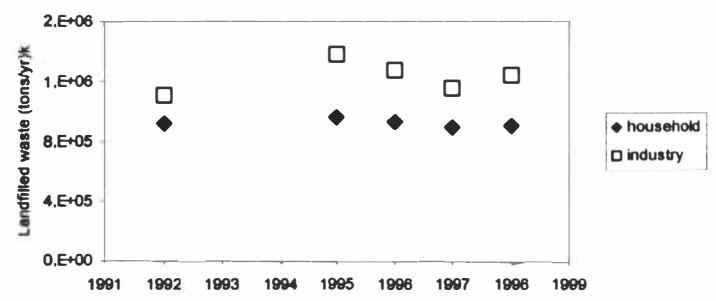

Figure 1. Trends in landfilled waste in Norway (SSB, 2001).

There are more than 3000 landfills in Norway, of which more than 500 are industrial, more than 1000 are municipal, and about 200 are in operation today. The public record of landfills has files for 1150 locations, of which 94 are registered closed. Total annual production of MSW is about 1.2 million tons (SSB, 1997). The volume of landfilled waste cannot be expected to decrease rapidly, in spite the effort to do so, see Figure 1. Both the public and government advocate more waste sorting, recycling and incineration to reduce landfilling. 20$30 \%$ of MSW landfills treat leachate at waste water treatment systems. Less than $10 \%$ receive some kind of local pre-treatment. Non-treated leachate is basically emitted from small landfills. The main recipients are fjord/coastal waters (36\%), rivers and streams (26\%) and soil $(25 \%)$ (SSB 1997). The specific leachate production measured at Norwegian landfills is $50-200 \mathrm{~m}^{3} / \mathrm{day}$, or $300-600 \mathrm{~mm} /$ year, about $30-60 \%$ of the precipitation, a relatively large production compared to other European countries. For on-site leachate treatment it is better to isolate the waste body from surface and groundwater from non-polluted areas. The hydrological properties of the landfill can be analysed with time series of leachate production and precipitation. Norwegian experiences show removals of COD 50-90\%, Fe $>70 \%$, Tot- $\mathrm{N}$ $30-50 \%$ and NH4-N 0-99\%. Seasonal effects have been observed (Mæhlum et al. 1998). High removal can be observed even during low temperatures or even floods due to the high buffering volume of the lagoon.

This study is based on detailed investigations of leachate from 3 landfills (Esval-referred to as e, Bølstad-referred to as b and Spillhaug as s), from the southeastern part of Norway, from 1992-to date. In addition leachate data from 10 other landfills representing a variety in size (5-50 ha), age and hydrology, have been compiled and are presented here. The specific landfills have been described earlier (Mæhlum et al., 1995). 


\section{METHODS}

All analyses are made at Jordforsk according to accredited methods and Norwegian standards. At Esval the leachate is sampled as weekly grab samples and analysed 6 to 8 times per year. The leachate volume is manually measured weekly. The electrical conductivity of the raw leachate is also sampled manually each week to monitor the weekly variability of the concentrations in the leachate. At Bølstad the leachate is sampled 6 to 8 times per year. The leachate volume is sampled continuously. At Spillhaug the leachate is analysed 5 to 10 times per year, and leachate volume is measured continuously. Leachate removal is calculated on a concentration basis without correction of $\mathrm{Cl}$ removal. Control calculations with removal on a weight basis showed little bias between the two methods. 
KALMAR ECO-TECH'01

Leachate and Wastewater Treatment with High-Tech and Natural systems

KALMAR, SWEDEN, November 26-28, 2001

\section{RESULTS}

The landfills and leachate systems are described in Table 1. The sites have a cool temperate continental climate, with $800 \mathrm{~mm}$ annual precipitation and a January mean air temperature around $-6^{\circ} \mathrm{C}$. Although leachate temperature and production rates are similar, one landfill (Esval) is about twice as large as the other two, see Table 1.

Table 1. Description of Esval, Bolstad and Spillhaug MSW landfills and treatment plants in Norway.

\begin{tabular}{|c|c|c|c|}
\hline General information & $\begin{array}{l}\text { Esval } \\
\text { Landfill }\end{array}$ & $\begin{array}{l}\text { Balatad } \\
\text { Landfill }\end{array}$ & $\begin{array}{l}\text { Spillhaug } \\
\text { Landfill }\end{array}$ \\
\hline Start operation & 1962 & 1972 (closed 1999) & 1973 \\
\hline Landfill area (1996) & $100 \mathrm{da}$ & 50 da & 60 da \\
\hline Landfill catchment area & $150 \mathrm{da}$ & 80 da & 150 \\
\hline Annual waste flow (1995) & $50000 t$ & $7000 \mathrm{t}$ & $10000 \mathrm{t}$ \\
\hline Total waste received & $500000 t$ & $190000 t$ & $200000 t$ \\
\hline Landfill depth & $25-30 m$ & $20 \mathrm{~m}$ & $30 \mathrm{~m}$ \\
\hline Waste type & MSW, septic sludge & MSW & MSW \\
\hline Annual mean precipitation & $825 \mathrm{~mm}$ & $785 \mathrm{~mm}$ & 800 \\
\hline Mearoair temp & $7^{\circ} \mathrm{C}$ & $6^{\circ} \mathrm{C}$ & $7^{\circ} \mathrm{C}$ \\
\hline Mean air temp Jan. & $-7^{\circ} \mathrm{C}$ & $-5^{\circ} \mathrm{C}$ & $-7^{\circ} \mathrm{C}$ \\
\hline Landfill sealing & day & clay & no \\
\hline Drainage system & gravel ditches & pipe & Sand/gravel aquifer \\
\hline $\begin{array}{l}\text { Leachate production } \\
\text { mean, Odim (range) }\end{array}$ & $120(30-800) \mathrm{m}^{3} / \mathrm{d}$ & $80(30-300) n 0^{3} / d$ & $130 \mathrm{nv}^{3} / \mathrm{d}$ \\
\hline Leachate temp Jan./June & $1^{\circ} \mathrm{RO} 0^{\circ} \mathrm{C}$ & $1 * / 20^{\circ} \mathrm{C}$ & $5 / 10^{\circ} \mathrm{C}$ \\
\hline \multicolumn{4}{|l|}{ Leachato treatmont systoms } \\
\hline Established & 1993 & 1994 & 1998 \\
\hline 1. Stage - pretreatment & anaerobic pond & none & Sandy aquifer, $300 \mathrm{~m}$ \\
\hline Aree & $450 \mathrm{~m}^{2}$ & - & HRT $40-50 \mathrm{~d}$ \\
\hline Volume & $650 \mathrm{~m}^{3}$ & - & \\
\hline 2. Stage - oxidation & aerated lagoon & aerated lagoon & aerated lagoon \\
\hline Aree & $2700 \mathrm{~m}^{2}$ & $1000 \mathrm{~m}^{2}$ & $1000 \mathrm{~m}^{2}$ \\
\hline Volume & $4100 \mathrm{~m}^{3}$ & $2200 n 0^{3}$ & $1800 \mathrm{~m}^{2}$ \\
\hline Aeration equipment & $\begin{array}{c}3 \text { floating aspirator propoller/mixers, } \\
\text { each } 5 \text { - } 10 \mathrm{~kW}\end{array}$ & $\begin{array}{c}1 \text { foating aspirator } \\
\text { propeller/mixer, } 10 \mathrm{~kW}\end{array}$ & $\begin{array}{l}1 \text { floating aspirator } \\
\text { propeller/mixers } 10 \mathrm{~kW}\end{array}$ \\
\hline 3. Stage - filterhwetland & 2 parallel SHF-CW & $\begin{array}{l}4 \text { parallal SHF-CW. } \\
\text { mesoscale }{ }^{c} \text { system }\end{array}$ & $\begin{array}{l}3 \text { free water CW in series } \\
\text { HRD7 - } 10 d\end{array}$ \\
\hline Aree & $2 \times 350 \mathrm{~m}^{2}$ & $4 \times(1 \times 10) \mathrm{m}^{2}$ & $3000 \mathrm{~m}^{2}$ \\
\hline 4. Stage & FWS-cWb & none & \\
\hline Area & $2000 \mathrm{~m}^{2}$ & $\cdot$ & \\
\hline Volume & $1000 \mathrm{~m}^{2}$ & - & \\
\hline Totel costs & 200000 USD & 150000 USD & \\
\hline
\end{tabular}




\subsection{Esval}
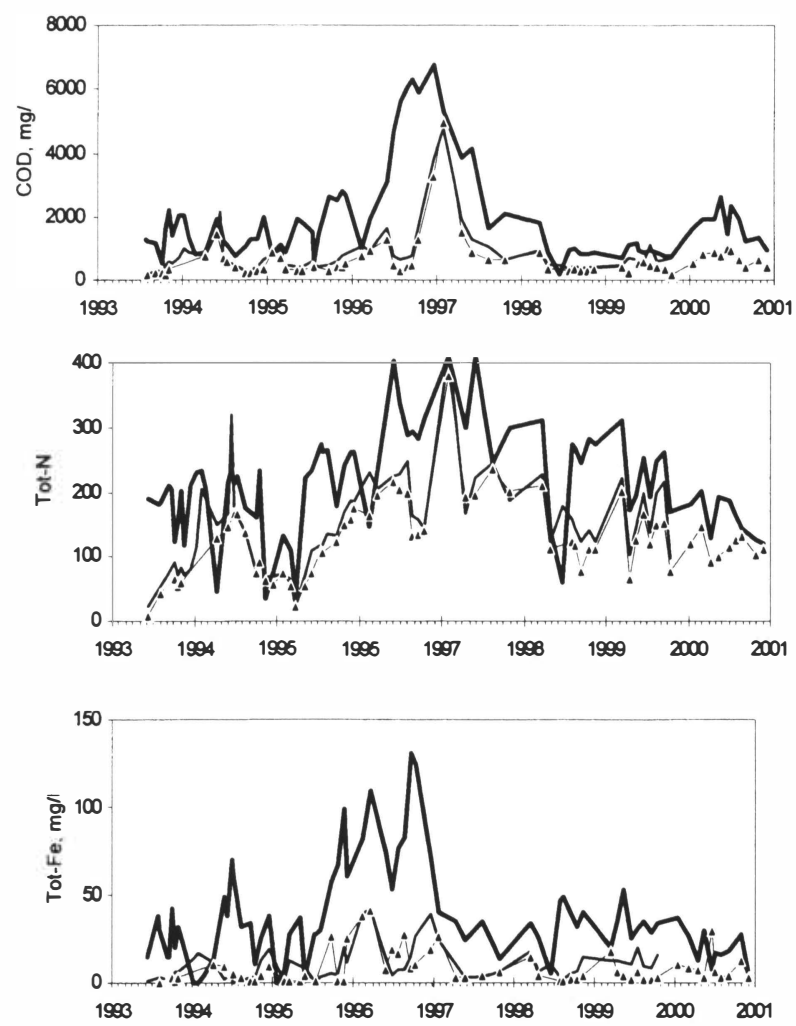

Figure 2. Time series in $\mathrm{mg} / \mathrm{L}$ of organic matter (COD), nitrogen (Tot-N) and iron (Tot-Fe) from Esval Landfill (raw leachate $=$ heavy line, lagoon=thin line, wetland=triangles)

The leachate at Esval has changed considerably during the operation of the treatment system. For $\mathrm{COD}$ and Fe there is a peak concentration from 1996-1997. The system has not been able to remove the prescribed $75 \%$ COD and $45 \%$ Tot-N. It is also clear that the wetland has low removal, mainly due to hydraulic and chemical overloading. 
KALMAR ECO-TECH'01

Leachate and Wastewater Treatment with High-Tech and Natural systems KALMAR, SWEDEN, November 26-28, 2001

\subsection{Bølstad}
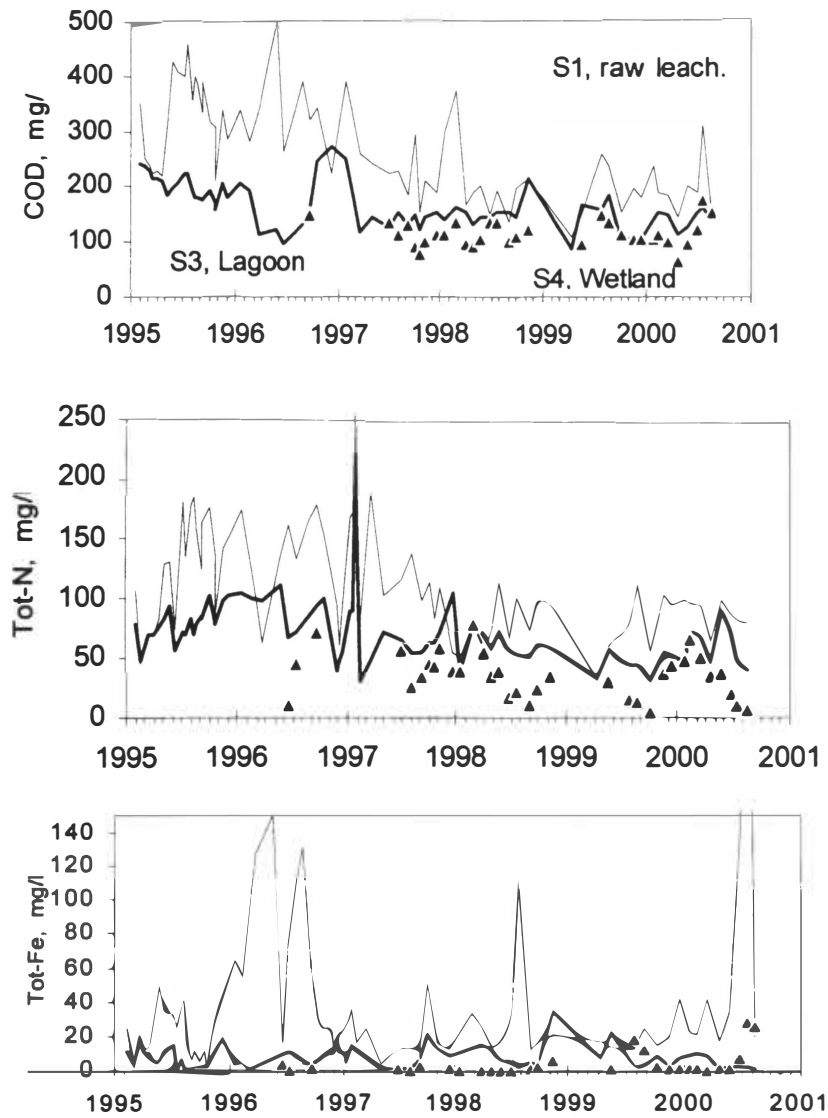

Figure 3. Time series in $\mathrm{mg} / \mathrm{L}$ of organic matter (COD), nitrogen (Tot-N) and iron (Tot-Fe) from Bolstad Landfill (raw leachate=line, lagoon=heavy line, wetland=triangles).

At Bølstad the wetland has higher removal. Also here the removal of COD is not up to the target value of $75 \%$ removal. 


\subsection{Spillhaug}
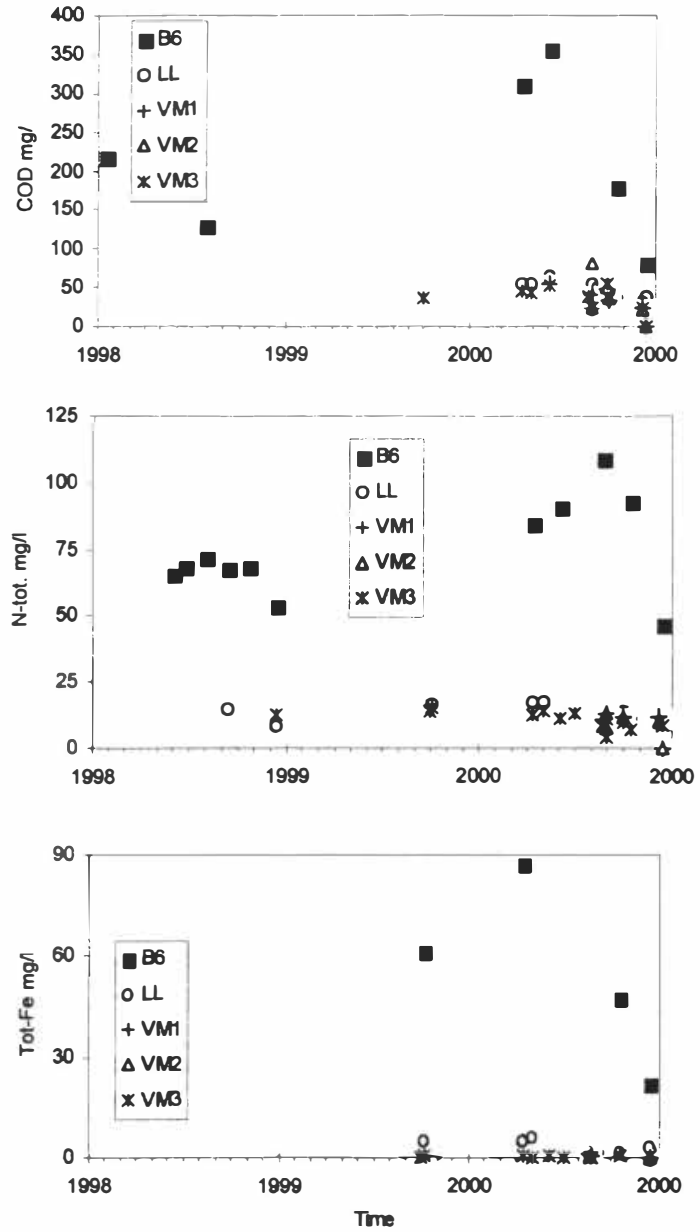

Figure 4. Trends in COD, Tot-N and Fe at Spillhaug landfill (B6=upstream groundwater well close to the landfill, $L L=$ aerated lagoon, $V M 1-3=$ wetlands)

At Spillhaug the removal is above the target values. Here the concentrations are much lower due to infiltration to groundwater before treatment in the lagoon and wetlands. 
KALMAR ECO-TECH'01

Leachate and Wastewater Treatment with High-Tech and Natural systems

KALMAR, SWEDEN, November 26-28, 2001

\section{SUMMARY}

Figures 2-4 shows that the leachate at Esval is moderatly strong, and at Bølstad and Spillhaug the leachates are weak. Esval experienced an increase in concentrations during 1996-1998, probably due to high input of waste producing leachate in the acetogenic phase. 2000 was a exceptionally wet year and can be seen as an increase in COD and N concentrations at Esval and Bølstad. A summary of the annual mean removal of organic matter, nitrogen and iron is shown in Table 2.

Table 2. Time series of annual mean removal, systems including all treatment stages (\%)

\begin{tabular}{rrrrrrrrrr}
\hline & \multicolumn{3}{c}{ Esval } & \multicolumn{3}{c}{ Bølstad } & \multicolumn{4}{c}{ Spillhaug } \\
\hline Year & COD & N & Fe & COD & N & Fe & COD & N & Fe \\
1993 & 86 & 83 & 89 & & & & & & \\
1997 & 65 & 45 & 80 & 38 & 43 & 61 & & & \\
1998 & 56 & 47 & 87 & 27 & 26 & 64 & & & 97 \\
1999 & 53 & 40 & 84 & 36 & 68 & 70 & 75 & 80 & 99 \\
2000 & 59 & 28 & 55 & 41 & 60 & 90 & 81 & 87 & 99 \\
\hline
\end{tabular}

Table 2 shows that for the two landfills Esval and Bølstad, the removal of organic matter and nitrogen is occasionally below target values, usually $75 \%$ removal for COD and $45 \%$ for total nitrogen. The systems are better in removing iron (and other metals). The reasons for malfunctioning of the systems can be several: the hydraulic loading or the loading of organic matter and nutrients is higher than the system design, the hydraulic detention time is not according to specifications (shortcuts), flooding and erosion of the lagoons, or the leachate is too toxic for the given treatment option.

The hydraulic retention time should to be $>20$ days to keep the nitrifiers in the lagoon during periods with low temperatures. Liquid temperature will be an important factor especially at high latitudes.

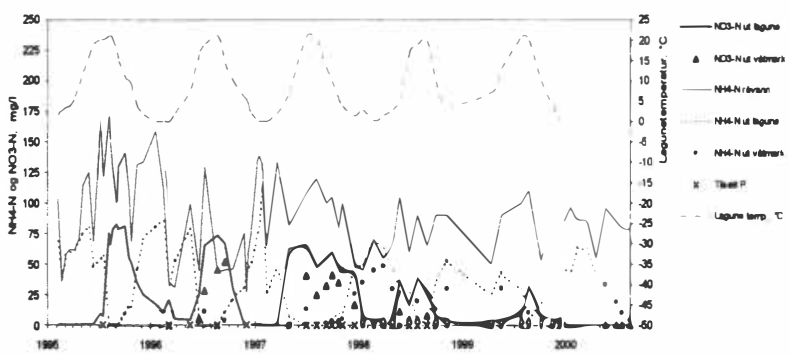

Figure 5. Lagoon temperature and concentrations of NO3-N and NH4-N in raw leachate and effluent aerated lagoon and $C W$ (mesoscale) of landfill $b$, as response to changing temperatures and addition of supplemental phosphorous. 
KALMAR ECO-TECH'01

Leachate and Wastewater Treatment with High-Tech and Natural systems

KALMAR, SWEDEN, November 26-28, 2001

\section{REFERENCES}

1. Ashbee, E. and I. Fletcher. (1993). Reviewing the options for leachate treatment. Wastes Management, 8, 32-33.

2. Haarstad, K., Mæhlum, T. 1999. MSW Leachate variability and alternative pre-treatment filter in cold, temperate climates. In: Christensen, T.M., Cossu, R., Stegmann, R. (Eds.): Leachate, gas, operation and health effiects in landfills. Proceedings Sardinia 99, Vol. II. CISA, via Marenge 34, I-09123 Cagliari, pp. 215-224.

3. Mæhlum, T., Haarstad, K. and Kraft, P. (1995). On-site treatment of landfill leachate in natural systems. In: Christensen, T.H., Cossu, R. and Stegmann, R.: Proc. Sardinia 1995, Fifth Int. Landfill Symp, Cagliari, Italy., Vol 1, 463-468.

4. Mæhlum, T., Haarstad, K. 1997. Leachate treatment in ponds and wetlands in cold climate. In: Christensen, T.M., Cossu, R., Stegmann, R. (Eds.): Leachate and landfill gas management. Proceedings Sardinia 97, Vol. II. CISA, via Marenge 34, I-09123 Cagliari, pp. 337-344.

5. Maris, P.J. and Harrington, D.W. (1984). Leachate treatment with particular reference to aerated lagoons. Water Pollution Control, 83, 4, 521-538.

6. Martin, C.D. and Moshiri, G.A. (1992). Nutrient reduction in an in-series constructed wetland system treating landfill leachate. In: Proc. International Specialist Conference - Wetland Systems in Water Poilution Control. University of New South Wales, Sydney, Australia.

7. Robinson, H.D. and Maris, P.J. (1985). The treatment of leachates from domestic waste in landfill sites. Journal WPCF, 57, 1, 30 - 38.

8. Robinson, H. R. and Grantham, G. (1988). The treatment of landfill leachates in on-site aerated lagoon plants: Experience in Britain and Irland. Wat.Res., 22, 6, 733 - 747.

9. Robinson, H.D. (1990). On-site treatment of leachates from landfilled wastes. Journal of The Institution of Water and Environmental Management, 4, 1, 78 - 89. London, England.

10. Robinson, H.D., Last, S.D., Raybould, A., Savory, D., Walsh, T.C. 1997. State of the art landfill leachate treatment schemes in the United Kingdom. In: Christensen, T.M., Cossu, R., Stegmann, R. (Eds.): Leachate and landfill gas management. Proceedings Sardinia 97, Vol. II. CISA, via Marenge 34, I-09123 Cagliari, pp. 191-210.

11. SSB. State pollution agency. 2001.

http://www.ssb.no/emner/01/05/avfall_tab_fig/tab_fig_reg.html\#kommunalt 